\title{
Vezane fenolne spojine polnozrnatih žitnih pripravkov kot sestavina funkcionalnih živil: drugi del
}

\author{
Petra TERPINC ${ }^{1}$
}

Received September 9, 2019; accepted December 2, 2019.

Delo je prispelo 09. septembra 2019, sprejeto 02. decembra 2019. Vezane fenolne spojine polnozrnatih žitnih pripravkov kot
sestavina funkcionalnih živil: drugi del

Izvleček: Hrana na bazi žit bistveno prispeva k vnosu energije $\mathrm{v}$ človeško telo, saj se pogosto znajde na naših jedilnikih, medtem ko polnozrnata živila iz žit pripomorejo $\mathrm{k}$ večjemu vnosu mikronutrientov kot, če ta uživamo v prečiščeni obliki. Vezane fenolne spojine, ki so nakopičeni v otrobih žit, se transformirajo $\mathrm{v}$ dvanajstniku, $\mathrm{v}$ debelem črevesu pa jih prisotna mikrobiota $\mathrm{v}$ procesu fermentacije pretvori $\mathrm{v}$ metabolite, ki se lahko absorbirajo. V drugem delu je predstavljena analiza fenolnih spojin, s poudarkom na hidrolizi in ekstrakciji vezanih fenolnih spojin, njihovi kvantifikaciji ter identifikaciji. Ker slaba biorazpoložljivost neekstraktibilnih fenolnih spojin kritično omejuje izkoriščanje njihovega širokega potenciala, se v članku dotaknemo tudi tehnik in novih strategij, s katerimi je možno sprostiti fenolne spojine iz netopno vezanih oblik $\mathrm{z}$ obdelavo živil. Pobližje se spoznamo $\mathrm{z}$ dvema trenutno zelo aktualnima pristopoma, kaljenjem in fermentacijo. S transformacijo vezanih fenolnih spojin v lažje dostopne proste fenolne spojine, lahko poleg ugodnega antikancerogenega učinka na debelo črevo, izkoristimo tudi njihovo antioksidativno in protimikrobno učinkovitost. Zavedanje potrošnikov in njihovo povpraševanje po zdravi hrani je privedlo do zahtev po vključevanju naravnih sestavin v proizvodnjo izdelkov z dodano vrednostjo. Pridobivanje ferulne kisline iz polnozrnatih pripravkov žit in njihova vključitev v funkcionalne prehrambene proizvode je vsekakor pomembno raziskovalno področje $\mathrm{v}$ prihodnosti.

Ključne besede: polnozrnati žitni izdelki; hidroliza vezanih fenolnih spojin; biorazpoložljivost fenolnih spojin; kaljenje; fermentacija; funkcionalna živila
Bound phenolic compounds of whole cereal grains as a functional food component: part two

Abstract: Since they are eaten regularly, cereals based food make a significant contribution to the daily energy intake, meanwhile in whole-grain form they contribute to higher micronutrients intake that refined cereal products. The bound phenolic compounds, which are accumulated in cereal bran, play a key role in the duodenum, where they are transformed to the absorbable metabolites by microbial fermentation. In part two, an analysis of phenolic compounds is presented, with emphasis on the hydrolysis and extraction procedure for bound phenolic compounds, their quantification and identification. Due to poor bioavailability of non-extractable phenolic compounds, which critically limits the exploitation of their wide potential, the article also discusses techniques and new strategies that enable the release of phenolic compounds from insoluble bound forms during food processing. Two current approaches, germination and fermentation, are presented in more details. With transformation of bound phenolic compounds to more easily accessible free phenolic compounds, we also benefit from their antioxidant and antimicrobial efficacy in addition to a favorable anti-cancer effect on the colon. The awareness of consumers and their demand for healthier foods led to the exploration and incorporation of natural ingredients in the production of value added products. The extraction of ferulic acid from whole grain cereal products and its incorporation in functional food products is definitely an important area of future research.

Key words: whole-grain cereal products; hydrolysis of bound phenolic compounds; bioavailability of phenolic compounds; germination; fermentation; functional foods

1 Univerza v Ljubljani, Biotehniška fakulteta, Jamnikarjeva 101, SI-1000 Ljubljana, e-mail: petra.terpinc@bf.uni-lj.si 


\section{ANALIZA FENOLNIH KISLIN}

Glede na različno naravo fenolnih kislin, ki jih najdemo v žitih, je pomembno izbrati metodo, ki v največji možni meri zajame vse tarčne molekule. Analiza fenolnih kislin sestoji iz več korakov, postopek običajno vključuje ekstrakcijo, hidrolizo, čiščenje oz. izolacijo, identifikacijo in kvantifikacijo. V Preglednici 1 so navedene posamezne fenolne kisline in njihova razširjenost med žiti in psevdožiti.

Ne glede na vrsto žita, je eden ključnih korakov homogenizacija vzorca. Ta zagotavlja reprezentativen vzorec (ustrezen delež endosperma, kalčka in zunanjih plasti), po drugi strani pa le zadostna homogenizacija omogoča dobro ekstraktibilnost in analitično ponovljivost. Zmanjšanje velikosti delcev vpliva na prenos mase. $\mathrm{Z}$ namenom zagotavljanja čim večje kontaktne površine med tarčnimi molekulami in ekstrakcijskim topilom, se v literaturi največkrat omenja mletje, redkeje pa drobljenje $\mathrm{v}$ možnarju ali uporaba stiskalnice (Domínguez-Rodríguez in sod., 2017). Pred homogenizacijo je vzorec priporočljivo stabilizirati s tekočim dušikom (inaktivacija encimov, ohranjanje fenolnih spojin), pa tudi sicer je pomembno, da se analiza izvede čim hitreje po zaključeni homogenizaciji. Obstajajo številni dokazi, da na izplen fenolnih spojin v veliki meri vplivajo razmere ekstrakcije, med drugim izbira ekstrakcijskega topila (Gunenc in sod., 2015), način ekstrakcije (Kumar in sod., 2016), čas in temperatura ekstrakcije (Wang in sod., 2008). Domínguez-Rodrígu- ez in sod. (2017) opozarjajo, da je potrebno v vzorcu upoštevati tudi vsebnost vode. Sušenje vzorca lahko povzroči kontrakcijo celic, kar potencialno ovira ekstrakcijo analita iz notranjosti celice. Zato je vpijanje vode in nabrekanje celic do določene mere zaželeno, vendar je prisotnost vode sočasno $\mathrm{v}$ tesni korelaciji $\mathrm{z}$ zmanjšano stabilnostjo vzorca (nastale spremembe so posledica kemijskih in encimskih reakcij). Sušenje na zraku je dolgotrajen postopek, ki zahteva relativno visoke temperature, kar lahko vodi v pretvorbe fenolnih spojin. Dobro alternativo, ki zagotavlja maksimalno dobit in ohranitev fenolnih spojin, predstavljata sušenje $\mathrm{z}$ zamrzovanjem (liofilizacija) in vakuumsko sušenje.

Ekstrakcijske tehnike delimo na konvencionalne in napredne. Prvi sklop je osnovan na principu solventne ekstrakcije, tj. uporabi organskih topil (primeri: metanol, etanol, aceton) ali mešanici topil (metanol/ voda, nakisan metanol/voda, aceton/voda,...) (Domínguez-Rodríguez in sod., 2017). Zaradi več hidroksilnih skupin (ki so polarne) in aromatskega obroča (ki je nepolaren), je večina fenolnih spojin, ki na svoj osnovni skelet nimajo pripete dodatne molekule, dobro topna $\mathrm{v}$ polarnih in srednje nepolarnih topilih (voda/aceton/ metanol in dietileter/etilacetat). Iz tega razloga jih lahko opredelimo kot topne proste fenolne spojine. Topni konjugati sestojijo iz fenolne spojine in polarnega dela (v žitih najpogosteje sladkorja), ki poveča topnost fenolnih spojin $\mathrm{v}$ polarnih topilih. Posledično lahko tudi topne konjugate ekstrahiramo s polarnimi topili kot so voda, metanol, aceton oz. jih očistimo prostih

Preglednica 1: Razdelitev fenolnih kislin in njihova prisotnost v zrnih žit in psevdožit (povzeto po Irakli in sod. (2012a); Wang in sod. (2014); Călinoiu in Vodnar (2018); Van Hung (2016); Gawlik-Dziki in sod. (2012); Tang in sod. (2016); Dykes in Rooney (2007); Mir in sod. (2018)).

Table 1: Classification of phenolic acids and their presence in cereal and pseudocereal grains (summarized by Irakli et al. (2012a); Wang et al. (2014); Călinoiu and Vodnar (2018); Van Hung (2016); Gawlik-Dziki et al. (2012); Tang et al. (2016); Dykes and Rooney (2007); Mir et al. (2018)).

\begin{tabular}{|c|c|c|c|}
\hline & Fenolna kislina & Žito & Psevdožito \\
\hline \multirow{7}{*}{ 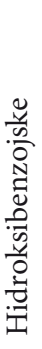 } & Galna & Riž, proso, oves, pšenica, pira, ječmen, rž, koruza, tritikala & Amarant, ajda, kvinoja \\
\hline & Gentistična & Proso, pšenica & \\
\hline & p-Hidroksibenzojska & Ječmen, oves, riž, proso, pšenica, pira, koruza, rž, tritikala & Amarant, ajda, kvinoja \\
\hline & Protokatehuična & Riž, proso, rž, ječmen, oves, koruza, pšenica, pira, tritikala & Amarant, kvinoja \\
\hline & Salicilna & Pšenica, pira, ječmen, oves, tritikala & \\
\hline & Siringična & Pšenica, pira, koruza, oves, proso, ječmen, rž, riž, tritikala & Amarant, kvinoja \\
\hline & Vanilinska & Ječmen, oves, proso, pšenica, pira, rž, koruza, riž, tritikala & Amarant, ajda, kvinoja \\
\hline \multirow{5}{*}{ 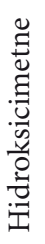 } & Cimetna & Proso, pšenica, oves & Kvinoja \\
\hline & Ferulna & Koruza, pšenica, pira, ječmen, rž, proso, riž, oves, tritikala & Ajda, kvinoja \\
\hline & Kavna & Oves, riž, ječmen, pšenica, pira, koruza, proso, rž, tritikala & Ajda, kvinoja \\
\hline & p-Kumarna & Koruza, pšenica, pira, ječmen, rž, proso, riž, oves, tritikala & Amarant, ajda, kvinoja \\
\hline & Sinapinska & Rž, riž, pšenica, pira, koruza, ječmen, proso, oves, tritikala & Ajda, kvinoja \\
\hline
\end{tabular}


fenolnih spojin s pomočjo dietiletra/etilacetata $(\mathrm{Xu}$ in sod., 2019). Ekstrakcijo trdno-tekoče (kadar je matriks v trdni obliki) ali tekoče-tekoče (kadar je vzorec tekoč) lahko uporabimo tudi kot fazo čiščenja za odstranitev ekstraktibilnih fenolnih spojin. Če želimo v vzorcu določiti netopno vezane fenolne spojine, ga moramo najprej z opisanim postopkom očistiti prostih fenolnih spojin in topnih konjugatov (Domínguez-Rodríguez in sod., 2017).

$\mathrm{V}$ zadnjem desetletju konvencionalne ekstrakcijske metode vse pogosteje nadomeščajo sodobne tehnike, ki imajo številne prednosti: so hitrejše, avtomatizirane, bolj ponovljive in selektivne, zagotavljajo boljši izkoristek ekstrakcije, zahtevajo manjšo poraba toksičnih topil oz. vključujejo topila, ki so za okolje manj škodljiva. Mednje uvrščamo uporabo ultrazvoka, mikrovalov, pulzirajočega elektromagnetnega polja, encimov, visokega hidrostatičnega tlaka, tekočin pod pritiskom in superkritičnih tekočin (Dahmoune in sod., 2014; Das in sod., 2017; Kumar in sod., 2016). Po uporabi omenjenih tehnik, netopne fenolne spojine praviloma še vedno ostajajo vezane na celični matriks (Domínguez-Rodríguez in sod., 2017). Slabo topni polimeri kot so celuloza, arabinoksilan, hemiceluloza ali kompleks polisaharid-protein, onemogočajo topnost vezanih fenolnih spojin v vodi in organskih topilih, zato jih pojmujemo tudi kot netopne ali neekstraktibilne fenolne spojine. Fenolne kisline bolj ali manj uspešno sprostimo iz vezane oblike, če vzorec obdelamo z bazo, kislino ali encimi, pri čemer je izplen odvisen od razmer hidrolize (Acosta-Estrada in sod., 2014; Arranz in Saura Calixto, 2010; Kim in sod., 2006; Verma in sod., 2009). V povezavi s prekinitvijo glikozidnih in estrskih vezi, ki jih fenolne spojine najpogosteje tvorijo v žitnih zrnih, se v dosedanjih raziskavah največkrat omenjata alkalna in kislinska hidroliza. Eden izmed možnih pristopov za analizo prostih, konjugiranih in netopno vezanih fenolnih spojin je prikazan na Sliki 1 in podrobneje predstavljen v eni naših prejšnjih raziskav (Terpinc in sod., 2011a). Hidrolizi (alkalni, kislinski, kombinirani), ki sprosti topne in netopno vezane fenolne spojine, običajno sledi ekstrakcija hidroliziranih molekul s pomočjo etilacetata, dietiletra ali zmesi etilacetata in etra (v razmerju 1:1).

Kislinska hidroliza povzroči razpad glikozidnih vezi in sprosti se sladkorni del, medtem ko običajno na estrske vezi nima vpliva (Domínguez-Rodríguez in sod., 2017). Različni raziskovalci (Chen in sod., 2014; Kim in sod., 2006) poročajo, da vodi kislinska hidroliza pri povišanih temperaturah do izgub določenih fenolnih spojin, tvorbe furfurala in njegovih derivatov. $\mathrm{Na}$ drugi strani lahko $\mathrm{z}$ alkalno hidrolizo sprostimo fenolne spojine iz polisaharidov tako, da razcepimo estrske vezi. Obdelava vzorca $z$ različnimi koncentracijami na- trijevega hidroksida se je izkazala kot učinkovit način sproščanja omenjenih tarčnih molekul iz riža (Irakli in sod., 2018), pšenice (Zhang in sod., 2018), ovsa in ječmena (Gangopadhyay in sod., 2015). Postopek naj ne bi vodil v kemijsko modifikacijo fenolnih spojin (Domínguez-Rodríguez in sod., 2017). Tako kislinska kot alkalna hidroliza sta nespecifični in lahko privedeta do strukturnih sprememb na fenolnih spojinah, zaradi česar ne moremo sklepati o strukturi izhodnih spojin $\mathrm{v}$ netretiranem vzorcu. Bolj specifična, netoksična in učinkovita metoda vključuje uporabo encimov: glukoronidaz, pektinaz, celulaz, hemicelulaz, glukanaz, tanaz in amilaz. Kljub številnim prednostim, je uporaba encimov za razcep glikozidnih vezi in razgradnjo celične stene slabo razširjena $\mathrm{v}$ praksi, predvsem na račun njihove omejene uporabe. Encimi za svoje delovanje običajno potrebujejo mile pogoje delovanja $(\mathrm{pH}$, temperatura in tlak). K manjšemu izplenu netopne frakcije pripomore tudi velik delež celuloze in lignina $\mathrm{v}$ celičnih stenah rastlin. Eden učinkovitejših pristopov je kombinacija različnih načinov hidrolize. Alves in sod. (2016) so ugotovili, da predhodno tretiranje vzorca $\mathrm{Z}$ a-amilazami (15 min obdelava pri $37^{\circ} \mathrm{C}$ ) zmanjša viskoznost hidrolizata (alkalna hidroliza je prav tako potekala pri $37^{\circ} \mathrm{C}$ ) in tako za več kot trikrat poveča ekstraktibilnost vezanih fenolnih spojin v primerjavi s klasično alkalno hidrolizo pri sobni temperaturi, oz. je izplen primerljiv z alkalno hidrolizo pri $70{ }^{\circ} \mathrm{C}$. Čeprav velja kemijska hidroliza za učinkovit pristop študije vezanih fenolnih spojin, te metode običajno vključujejo visoke temperature in ostre alkalne ali kisle razmere. Ti kot taki ne odražajo realnega stanja v človeškem telesu (Acosta-Estrada in sod., 2014), zato je relevantnost dobljenih rezultatov vprašljiva.

Določitev prostih in vezanih fenolnih spojin $\mathrm{v}$ žitih običajno zahteva dodaten korak, ki je namenjen odstranitvi interferenc in koncentriranju vzorcev. Z ekstrakcijo na trdnem nosilcu (SPE) lahko iz žitnih zrn učinkovito odstranimo sladkorje in druge relativno polarne spojine: organske kisline, aminokisline, proteine. Številni poskusi optimizacije omogočajo velike izkoristke in dobro ponovljivost (Irakli in sod., 2012a, 2012b).

Najbolj razširjen način za ločitev in karakterizacijo posameznih fenolnih spojin je HPLC. Čeprav je znotraj omenjene tehnike možna uporaba številnih kolon, se večina analitikov odloči za uporabo kolone $\mathrm{z}$ reverzno fazo C16 ali C18, ki izboljša separacijo analitov. Izbira mobilne faze lahko variira, vendar ta običajno vključuje gradientno spreminjanje razmerja med organsko in vodno fazo. Slednji se $\mathrm{z}$ namenom učinkovitejše ločbe in resolucije kromatografskih vrhov pogosto doda ocetno ali mravljično kislino. Še nedolgo tega so za prvo izbiro 


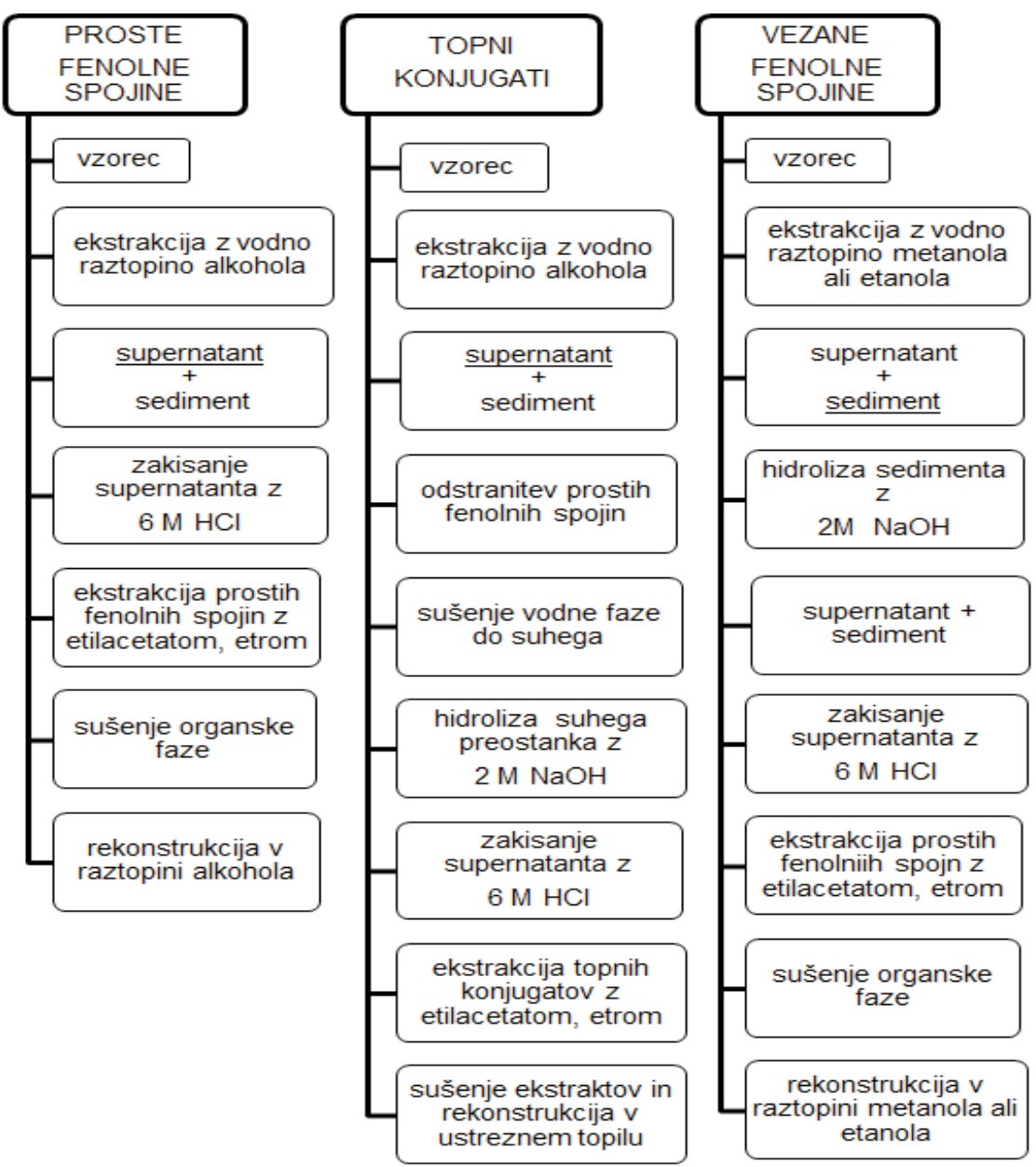

Slika 1: Protokol za analizo različnih oblik fenolnih spojin:. v prvi stopnji (stolpec levo) iz vzorca z ekstrakcijskim topilom (običajno $\mathrm{z}$ vodno raztopino alkohola) pridobimo ekstraktibilne fenolne spojine. Za uspešen prehod prostih fenolnih spojin iz bolj $\mathrm{v}$ manj polarno topilo (običajno dietileter in/ali etilacetat) je potrebno zagotoviti dovolj nizek pH (ker je topnost tarčnih fenolnih kislin v posamezni fazi odvisna od njihove pKa vrednosti), čemur sledi rekonstrukcija prostih fenolnih spojin v ustreznem topilu za nadaljnje analize. Po odstranitvi prostih fenolnih spojin se v vodni raztopini alkohola (supernatantu) nahajajo topni konjugati, ki jih podvržemo hidrolizi (stolpec na sredini), čemur sledi zakisanje hidrolizata in ekstrakcija sproščenih topno vezanih fenolnih spojin z organskim topilom. Prav tako je hidroliza potrebna v primeru netopno vezanih fenolnih spojin (stolpec desno). Slednjo izvedemo tako, da trdemu preostanku po ekstrakciji dodamo $\mathrm{NaOH}$, in nadaljujemo s protokolom za ekstrakcijo prostih fenolnih spojin.

Figure 1: Protocol for the analysis of different forms of phenolic compounds: in the first step (left column), extractable phenolic compounds are obtained from the sample with an extraction solvent (usually an aqueous alcoholic solution). A successful transition of free phenolic compounds from more to less polar solvent (usually diethyl ether and/or ethyl acetate) requires a sufficiently low $\mathrm{pH}$ (since the solubility of the target phenolic acids depends on their pKa value), followed by the reconstruction of free phenolic compounds in appropriate solvent for further analysis. After removal of free phenolic compounds, soluble conjugates are present in the aqueous alcoholic solution (supernatant) and subjected to hydrolysis (middle column), followed by acidification of the hydrolyzate and extraction of the released soluble phenolic compounds with an organic solvent. Hydrolysis is also required in the case of insoluble phenolic compounds (right column). The latter is carried out by the addition of $\mathrm{NaOH}$ to the solid residue after extraction, followed by the protocol for the extraction of free phenolic compounds.

organske faze veljala topila kot so propanol, butanol ali etilacetat, ki pa so jih $\mathrm{v}$ zadnjem času v veliki meri nadomestila predvsem metanol ali acetonitril (Koistinen in Hanhineva, 2017).
HPLC instrumenti so pogosto sklopljeni z UV/ Vis ali DAD detektorjem. Fenolne kisline v žitnih zrnih absorbirajo svetlobo različnih valovnih dolžin, odvisno od strukture molekule. Za derivate benzojske kisline je 
to območje med 200 - $290 \mathrm{~nm}$, za spojine, ki izhajajo iz cimetne kisline pa 270 - $360 \mathrm{~nm}$. Ta tip detekcije ne pove ničesar o strukturi posameznih spojin. Zaradi boljše občutljivosti, širšega območja detekcije in večje natančnosti, je UV-VIS detektor v veliki meri nadomestila masna spektroskopija (MS) (Koistinen in Hanhineva, 2017). Med najpogostejšimi načini ionizacije se omenja elektrosprej ionizacijo (ESI), ki pride $\mathrm{v}$ poštev za detekcijo toplotno občutljivih analitov $\mathrm{z}$ majhno in srednjo molsko maso. Ta pristop omogoča razlikovanje med različnimi fenolnimi spojinami in daje informacijo o položaju glikozidne vezi, glavno pomanjkljivost pa predstavlja pomanjkanje avtentičnih standardov (Domínguez-Rodríguez in sod., 2017). Strukturo vezanih fenolnih spojin lahko določimo tudi $\mathrm{z}$ uporabo jedrske magnetne resonance (NMR) (Anokwuru in sod., 2018; Wang in sod., 2015), ki ima številne prednosti pred MS, vendar se NMR v praksi zaradi visokih stroškov opreme in omejenega števila študij teh spojin, $\mathrm{v}$ ta namen uporablja relativno redko.

\section{SPROSTITEV VEZANIH FENOLNIH SPOJIN Z OBDELAVO ŽIVIL}

Medtem, ko nekatera semena stročnic in riž uživamo cela, večino žitnih zrn predelamo v moko. S tem vplivamo na matriks, tj. na okolico, v katero so hranila vgrajena znotraj zrna, posledično pa na samo razpoložljivost teh komponent (Oghbaei in Prakash, 2016). Nadalje je potrebno upoštevati način, kako je zrno vključeno v živilo, kot intaktno ali v zmleti obliki. Musa-Veloso in sod. (2018) so ugotovili, da je imelo uživanje kruha narejenega iz polnozrnate moke na dvig glukoze v krvi podobne posledice kot kruh iz bele, tj. prečiščene moke, medtem ko je dodatek celih zrn bistveno zmanjšal glikemični indeks.

Obdelava živil je eden ključnih korakov, ki določa kakšna bo biološka razpoložljivost in dostopnost bioaktivnih komponent. Na eni strani lahko obdelava živil vodi v zmanjšanje vsebnosti fenolnih spojin, hkrati pa obstajajo številni načini s katerimi olajšamo cepitev vezi, povečamo količino osvobojenih vezanih fenolnih spojin in izboljšamo njihovo absorpcijo $\mathrm{v}$ prebavilih (Călinoiu in Vodnar, 2018). Različni pristopi temeljijo na zmanjšanju velikosti delcev, razgradnji rastlinskega materiala in/ali razgradnji prehranske vlaknine. Struktura celičnega matriksa in pa način, kako je fenolna spojina vezana $\mathrm{v}$ ta matriks, pomembno vplivata na njeno fiziološko funkcijo (Ribas-Agustí in sod., 2018; Wang in sod., 2015). V sklopu mehanske obdelave omenimo mletje, drobljenje in brušenje. Pristop je osnovan na povečanju specifične površine delcev, ki ekstrakcij- skemu topilu omogoča lažji dostop do fenolnih spojin. $\mathrm{V}$ to skupino spada tudi mikrofluidizacija, ki temelji na homogenizaciji matriksa pod visokim tlakom brez uporabe organskih topil. Tudi tu pride do znatnega zmanjšanja redukcije velikosti delcev, pri čemer ti ekspandirajo, kar razrahlja njihovo trdno strukturo in tako olajša ekstrakcijo fenolnih spojin. Naslednjo kategorijo predstavlja toplotna obdelava, ki vključuje tehnike kot so parjenje, avtoklaviranje, sušenje in praženje. Predpostavlja se, da avtoklaviranje, zahvaljujoč visokim temperaturam in tlaku ter hitremu zmanjševanju tlaka ob zaključku procesa, omogoči sprostitev vezanih fenolnih spojin na račun porušene strukture celične stene in delne hidrolize prehranske vlaknine. Toplotno obdelavo običajno spremlja tvorba novih spojin (npr. produktov Maillardove reakcije) z znatno antioksidativno učinkovitostjo. Eno novejših tehnik predstavlja tudi kuhanje $\mathrm{z}$ ekstrudiranjem, ki lahko, prav tako kot neustrezna toplotna obdelava, povzroči razpad termolabilnih molekul. Omenjeni proces prekine integriteto celične stene in kovalentne vezi v fenolnih kompleksih $z$ veliko molsko maso se razcepijo. Med različnimi načini transformacije vezanih fenolnih spojin, velja izpostaviti biološko transformacijo. Fermentacija in kaljenje trenutno predstavlja enega najbolj aktualnih področij $\mathrm{v}$ sklopu tovrstnih raziskav.

Kaljenje se že stoletja uporablja z namenom mehčanja strukture zrna, izboljšanja hranilne vrednosti in zmanjševanja antinutritivnih komponent. Proces kaljenja vpliva na okus, aromo, stabilnost in prebavljivost zrn (Singh in sod., 2015). Primarni cilj je spodbuditi razvoj hidrolitičnih encimov, sintezo novih in aktivacijo tistih, ki so $\mathrm{v}$ nekaljenem zrnu v neaktivni obliki. Biosintezne poti v kalečem zrnu vodijo do strukturnih sprememb obstoječih spojin kot tudi do sinteze novih, bioaktivno pomembnih molekul. Xu (2019) povzema, da se med kaljenjem $\mathrm{z}$ vidika metabolizma fenolnih snovi odvijajo trije procesi. Prvič, v celici se vrši sinteza fenolnih spojin iz glukoze ali aromatskih aminokislin. Pentozno-fosfatna pot, glikolitična in šikimatna pot zagotovijo prekurzorje, ki je največkrat fenilalanin. Ta se $\mathrm{v}$ citosolu pretvori $\mathrm{v}$ fenolne kisline, te pa $\mathrm{v}$ endoplazmatskem retikulumu naprej $\mathrm{v}$ flavonoide, stilbene, kumarine. Nastale molekule lahko v nadaljevanju polimerizirajo ali se vežejo $\mathrm{z}$ drugimi makromolekulami (polisaharidi, proteini, lipidi), ki jih celica tako vezane skladišči v celični steni ali vakuoli. Drugič, hidrolitični encimi med kaljenjem razgrajujejo makrohranila in posledično sproščajo fenolne spojine iz vezanih oblik. Tretjič, celica fenolne spojine potroši, ko ti lovijo proste radikale ali služijo kot intermediati signalnih molekul.

Znano je, da razmere namakanja (Xu in sod., 2009; Yang, 2001), temperatura kaljenja (Chavarín-Martínez 
in sod., 2019; Paucar-Menacho in sod., 2017), čas kaljenja (Kim in sod., 2018; Paucar-Menacho in sod., 2017) ter način osvetljevanja (Xiang in sod., 2017) značilno vplivajo na fenolni profil kaljenih žitnih zrn. V eni naših prejšnjih raziskav (Terpinc in sod., 2016) smo med drugim ugotavljali vpliv razmer kaljenja na fenolni profil dveh sort ajde. Daljše kaljenje je vodilo v večjo vsebnost skupnih fenolnih spojin. Presenetljivo smo največji relativni prirast opazili pri izoorientinu, orientinu in izoviteksinu, medtem ko se je vsebnost najbolj zastopane fenolne spojine, rutina, relativno malo spremenila. Biološka aktivacija zrn vpliva na vsebnost skupnih fenolnih spojin tako v kalčkih kot v preostalemu delu kalečega zrna, pri čemer je vpliv na ekstraktibilne fenolne spojine drugačen kot na vezane fenolne spojine (Gan in sod., 2017). Žal se številne raziskave zadnjih let (Boubakri in sod., 2017; Falcinelli in sod., 2017; Niroula in sod., 2019) še vedno osredotočajo na ekstraktibilne fenolne komponente, čeprav imajo tudi v kaljenih žitnih zrnih glavno vlogo vezane fenolne spojine (Chen in sod., 2017; Hung in sod., 2011; Ti in sod., 2014). V začetnih fazah kalitve poteka razgradnja makromolekul, tj. proteinov, ogljikovih hidratov, lipidov, kar vodi v porast njihovih presnovnih produktov, tj. prostih aminokislin, enostavnih sladkorjev in organskih kislin. Aktivnost hidrolitičnih encimov omogoča sprostitev fenolnih spojin iz celične stene, kar v začetni fazi pomeni upad vezane frakcije in porast proste (Hübner in Arendt, 2013). Alvarez-Jubete in sod. (2010) so primerjali vsebnost ekstraktibilnih fenolnih spojin v kaljenih zrnih ajde, amaranta, kvinoje in pšenice in zabeležili dvakratno povečanje proste frakcije $\mathrm{v}$ ajdi, pšenici in kvinoji, kar za štirikrat pa se je njihova vsebnost povečala $v$ amarantu. Kot že omenjeno, v kalčku poleg primarnih metabolitov med kaljenjem nastajajo tudi sekundarni metaboliti, vključno s fenolnimi spojinami. Ti se nato vgrajujejo v celične stene novo nastalih rastlinskih celic, kar pri starejših kalčkih vodi v ponoven porast vezanih fenolnih spojin in upad proste oblike (Gan in sod., 2017; Singh in Sharma, 2017). Da različne razmere kaljenja značilno vplivajo na razmerje med prostimi in vezanimi fenolnimi spojinami smo potrdili tudi z lastnimi raziskavami (Krek, 2018; Golob, 2018). Biosinteza in transformacija fenolnih spojin lahko nadalje zavisi tudi od stresnih razmer med kaljenjem (Chen in sod., 2019; Ma in sod., 2019), niso pa vse spojine enako dovzetne za tovrstne spremembe. Hung in sod. (2011) v svoji raziskavi navajajo, da je kaljenje pšenice vodilo $\mathrm{v}$ porast derivatov hidroksibenzojske kisline, medtem ko se je vsebnost derivatov hidroksicimetne kisline zmanjšala. H kopičenju vezanih fenolnih snovi je najbolj prispevala ferulna kislina, med prostimi fenolnimi spojinami pa siringična kislina. Med kaljenjem v zrnih žit poleg fenolnih kislin nastajajo tudi druge fenolne spojine $\mathrm{z}$ biološko učinkovitostjo. Ti in sod. (2014) poročajo o spremenjeni vsebnosti tako prostih kot vezanih flavonoidov v primerjavi z nekaljenim rižem. Nenazadnje, kot povzema Oghbaei in Prakash (2016), številne študije povezujejo kaljenje in slajenje žit $\mathrm{z}$ izboljšano prehransko vrednostjo, prebavljivostjo in lažjo dostopnostjo hranil ter manjšo vsebnostjo nekaterih antinutrientov.

Podobno kot kaljenje, tudi fermentacija spremlja človeka že zelo dolgo časa. Mehanizem, s katerim povečamo biorazpoložljivost in dostopnost nevezanih fenolnih spojin s pomočjo fermentacije vključuje tako encime iz žitnih zrn kot mikroorganizmov. Predpostavlja se, da encimi lahko katalizirajo razgradnjo celične stene, poleg tega pa naj bi proces fermentacije zajemal tako sintezo novih spojin kot tudi encimsko transformacijo različnih že prisotnih bioaktivnih komponent. Učinkovitost te tehnike (podobno kot pri ostalih) zavisi od vrste žita, vrste mikroorganizma in razmer same fermentacije (zlasti temperature, časa, pH) (Wang in sod., 2014). Kot že omenjeno, je ferulna kislina v glavnem vezana na arabinoksilane. Nadalje lahko pride tudi do kovalentnih povezav med dvema ferulnima kislinama, ki sta pritrjeni na sosednja arabinoksilana (Slika 2), ali do tvorbe med ostankom ferulne kisline in tirozinom. Encim, ki katalizira cepitev te vezi (kot tudi sprostitev ostalih hidroksicimetnih kislin iz vezanih oblik), se imenuje feruloil esteraza (tudi ferulna kislina esteraza). Uspešno so ga izolirali iz številnih plesni in bakterij, njeno aktivnost pa so zaznali celo $\mathrm{v}$ ječmenu in prosu; tako raznolik izvor daje feruloil esterazam zelo širok spekter optimalnih razmer delovanja ( $\mathrm{pH} 3.0$ - 10.0) in $\left(\mathrm{T} 20-75^{\circ} \mathrm{C}\right)$ ). Viri navajajo, da encim postane aktiven med kaljenjem, njegova aktivnost med kaljenjem postopoma upada, njegovo delovanje pa upočasni nizek pH $(3,5)$ in povišana temperatura. Številne raziskave v zadnjih letih potrjujejo smiselnost uporabe feruloil esteraz za ekstrakcijo bioaktivnih komponent (Gänzle, 2014; Faulds, 2010; Oliveira in sod., 2019).

Prisotnost omenjenega encima, ki katalizira razpad estrske vezi med ferulno kislino in sladkorjem so potrdili tudi $\mathrm{v}$ laktobacilih, ki so naravno prisotni $\mathrm{v}$ našem črevesju. $\mathrm{O}$ znatnem porastu skupnih prostih fenolnih spojin poročajo $\mathrm{v}$ primeru fermentacije pšeničnih otrobov (Moore in sod., 2007). Avtorji so neodvisno od seva kvasovk določili največji relativni prirast siringinske, manjši $p$-kumarne in najmanjši ferulne kisline. Hkrati pa je bil vpliv omenjenih kvasovk na vsebnost vanilinske kisline izrazito negativen, kar nakazuje na različno zmožnost presnavljanja različnih fenolnih kislin v vezani obliki. Zaporedna uporaba kaljenja in fermentacije lahko biorazpoložljivost vezanih fenolnih spojin še dodatno izboljša. V eni izmed takšnih razi- 


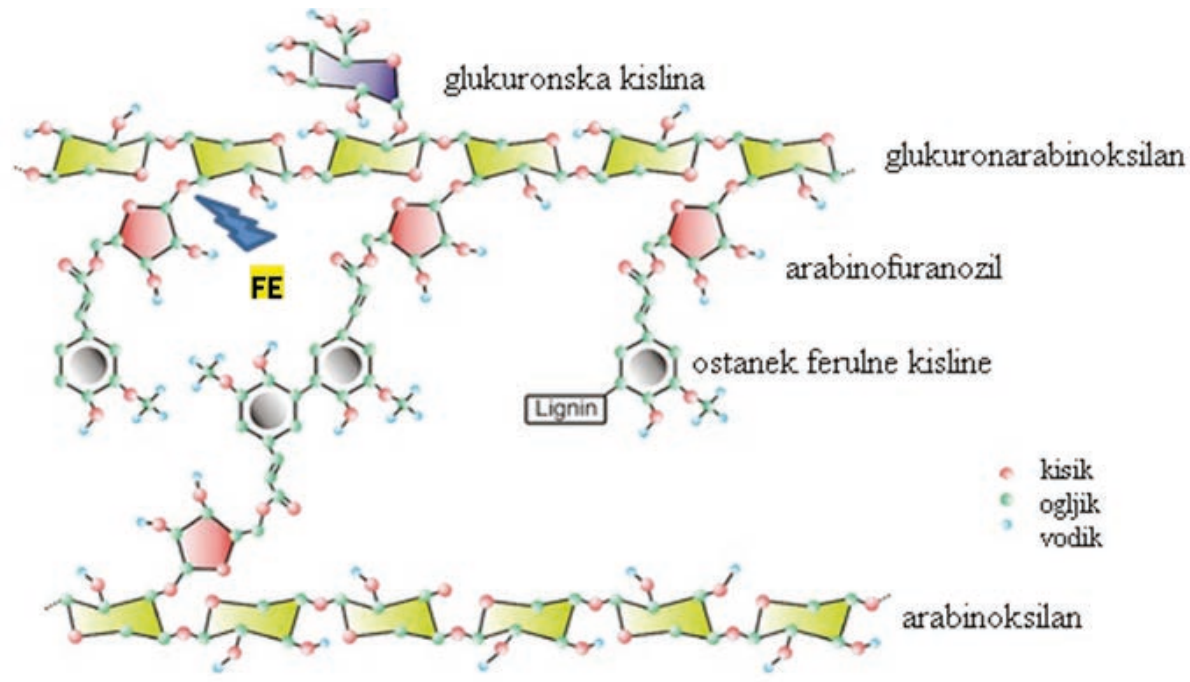

Slika 2: Celična stena je bogata $\mathrm{z}$ arabinoksilani. Osnovno ogrodje predstavlja veriga ksilana, ki je razvejana $\mathrm{z}$ arabinozo ali glukoronsko kislino. Arabinozni ostanki so pogosto zaestreni s s ferulno kislino, feruloilni estri polisaharidov lahko oksidativno polimerizirajo, kar vodi v nastanek dimerov in oligomerov, ki prečno povežejo bližnje glukoarabinoksilane; sprostitev ferulne kisline omogoča encim feruloil esteraza (FE) (prirejeno po de Oliveira in sod. (2015)).

Figure 2: Arabinoxylans are abundant in the cell wall. They are composed by a core chain of xylan branched with arabinose and glucuronic acid. The arabinose residues are often esterified with feruloyl residues, feruloyl esterified to polysaccharides can further oxidatively polymerize to produce dehydrodimer and oligomers that cross-link vicinal glucuronoarabinoxylan; ferulic acid can be released by the action of an enzyme feruloyl esterase (FE) (adapted by de Oliveira in sod. (2015)).

skav (Katina in sod., 2007) so z uporabo kvasovk ( $\mathrm{Sa}$ charomyces cerevisiae Meyen ex E.C. Hansen) znatno pripomogli k porastu vsebnosti skupnih fenolnih kislin in sicer za kar $110 \%$ (zgolj s kaljenjem je bilo povečanje $87 \%$ v primerjavi z nekaljenimi zrni). Fermentacija je bistveno pripomogla $\mathrm{k}$ dvigu prostih fenolnih kislin, zabeležili pa so tudi dvig zaestrenih, glikoziliranih in vezanih fenolnih kislin. Kot zanimivost povejmo, da so tako ob uporabi posamezne vrste mlečnokislinskih bakterij (Lactobacillus plantarum ((Orla-Jensen, 1919) Bergey in sod., 1923) ali Lactobacillus brevis) kot tudi mešane kulture (Saccharomyces cerevisiae, Lactobacillus plantarum in Lactobacillus brevis) ali celo spontane fermentacije, dobili primerljive rezultate za zaestrene, glikozilirane in vezane fenolne kisline, je pa v vseh naštetih primerih prišlo do izrazito negativnega vpliva na prosto frakcijo fenolnih spojin. Slednje ni v skladu z raziskavo, ki so jo Konopka in sod. (2014) opravili na pšenici in rži. Fermentacija s kvasovkami je povečala vsebnost proste ferulne kisline 10-krat, uporaba kislega testa pa 11-krat. Še večje razlike so se pokazale pri fermentaciji iz polnozrnate moke rži, kvasovke so vsebnost proste ferulne kisline povečala 13-krat, starter kultura mlečnokislinskih bakterij pa kar 25-krat. Tudi sicer lahko v nedavnem pregledu literature, ki jo je pripravil Gobbetti (2019), najdemo številne dokaze o smotrnosti uporabe kislega testa $\mathrm{z}$ namenom sprostitve vezanih fenolnih spojin. Antognoni in sod. (2019) poročajo o precejšnjemu doprinosu fermentacije $\mathrm{k}$ vsebnosti ferulne kisline. Trije izmed osmih preizkušenih sevov Lactobacillus plantarum so testo uspešno obogatili s prosto ferulno kislino, vendar kljub relativno zelo velikemu prirastu, je bila vsebnost prostih fenolnih spojin še vedno precej manjša od vsebnosti topnih konjugatov ter predvsem netopno vezane ferulne kisline. Avtorji so razlike pojasnili s tem, da imajo preizkušeni sevi različno sposobnost za prekinitev estrske vezi, s katero je ferulna kislina vezana na celično steno (torej preko aktivnosti esteraz) kot tudi na račun razlik v aktivnosti dekarboksilaz fenolnih kislin. Specifično sposobnost razgradnje/ hidrolize/ presnove fenolnih spojin s strani posameznih sevov mlečnokislinskih bakterij potrjuje tudi naslednja raziskava. Hole in sod. (2012) poročajo, da je fermentacija polnozrnatega ječmena in oluščenih zrn ovsa z izbranimi probiotičnimi bakterijami (Lactobacillus johnsonii, Lactobacillus reuteri (Kandler in sod., 1982), Lactobacillus acidophilus ((Moro, 1900) Hansen in Mocquot, 1970)) znatno povečala vsebnost prostih fenolnih kislin in tako posledično tudi njihovo biorazpoložljivosti. Raziskava je dala še en pomemben zaključek. Na primeru Bifidobacterium animalis ((Mitsuoka, 1969) Scardovi in Trovatelli, 1974) so pokazali, da velika aktivnost encima feruoil esteraze (ki je značilna tudi za zgoraj omenjene probiotike) še ne pomeni nujno velike 
učinkovitosti pri sproščanju vezane ferulne kisline. Fermentacija $\mathrm{z}$ mlečnokislinskimi bakterijami je vplivala tudi na spremembo skupnih vezanih fenolnih spojin, njihova vsebnost se je v ječmenu povečala, pri ovsu pa zmanjšala, prav tako je bil različen vpliv različnih bakterij na posamezne vezane fenolne kisline znotraj istega žita kot tudi med žiti. Porast vezane frakcije v ječmenu so raziskovalci povezali s povečano vsebnostjo topne vlaknine in posledično lažjo dostopnostjo (ekstraktibilnostjo) vezane frakcije.

\section{VEZANE FENOLNE SPOJINE V VLOGI BIOAKTIVNIH KOMPONENT}

V žitnih zrnih se nahaja veliko različnih komponent, ki po zaužitju vplivajo na zdravstveno stanje ljudi. Poleg zaviranja delitve rakavih celic $\mathrm{v}$ debelem črevesu (Madhujith in Shahidi, 2007; Shi in sod., 2015), uživanje vezanih fenolnih spojin povezujemo tudi z drugimi koristnimi posledicami. Katehinom in fenolnim kislinam pridobljenim iz golega ječmena Zhu in sod. (2015) pripisujejo inhibicijo rasti rakavih celic $\mathrm{v}$ jetrih. Raziskave opravljene na kvinoji (Hemalatha in sod., 2016; Tang in sod., 2016), so pokazale inhibitorni učinek na delovanje a-glukozidaze (ključni encim pri prebavi kompleksnih ogljikovih hidratov) in pankreasne lipaze (vloga pri absorpciji trigliceridov). Podobne rezultate je dala tudi študija fenolnih spojin, pridobljenih iz ovsa (Cai in sod., 2012) in prosa (Pradeep in Sreerama, 2017). Nadalje so raziskovalci (Boue in sod., 2016) na primeru barvnega riža ugotovili, da otrobi odstranjujejo glukozo iz krvnega obtoka $\mathrm{v}$ maščobne celice ter istočasno upočasnjujejo razgradnjo škroba do glukoze $\mathrm{v}$ tankem črevesu. Inhibicija $\alpha$-glukozidaze in pankreasne lipaze lahko predstavlja učinkovito strategijo uravnavanja nivoja glukoze v krvi in debelosti; dveh ključnih dejavnikov za razvoj sladkorne bolezni tipa 2 .

Nič manj ni pomembno njihovo antioksidativno, protivnetno in antimikrobno delovanje (Slavin, 2003). Vse fenolne kisline zahvaljujoč svoji strukturi izražajo določen antioksidativni potencial. Prostim radikalom oddajo elektron ali vodikov atom in jih tako stabilizirajo (Terpinc in Abramovič, 2010). Poleg tega ne smemo pozabiti tudi na njihove presnovne produkte. Eden takšnih, ki smo ga podrobneje že predstavili, 4-vinilgvajakol, se je izkazal kot uspešnejši antioksidant pri lovljenju alkilperoksilnega radikala $\mathrm{v}$ emulziji od svojega izvornega substrata, ferulne kisline (Terpinc in sod., 2011). Vezane fenolne spojine so $\mathrm{v}$ številnih in vitro antioksidativnih testih pokazali znatno večjo antioksidativno učinkovitost $\mathrm{v}$ primerjavi s prosto in konjugirano obliko (Chandrasekara in Shahidi, 2011; Chen in sod.,
2017; Liyana-Pathirana in Shahidi, 2006; Pang in sod., 2018). Literaturni viri navajajo, da so fenolni antioksidanti pšeničnih otrobov (Liyana-Pathirana in Shahidi, 2007; Yu in sod., 2005) sposobni inhibirati LDL oksidacijo, kot možen mehanizem se omenja vezavo apolipoproteinov B. Pred leti so $\mathrm{z}$ in vitro testi dokazali (Serpen in sod., 2007), da je alkalna hidroliza znatno zmanjšala antioksidativno učinkovitost spojin pridobljenih iz pšeničnih in ječmenovih otrobov, kar govori $\mathrm{v}$ prid teoriji, da so fenolne spojine bolj učinkovite pri lovljenju prostih radikalov, ko so fenolne spojine vezane na netopne komponente. Tudi v študiji, ki so jo Price in sod. (2012) opravili na zdravih, prekomerno hranjenih udeležencih, starih 45 - 65 let, se je na analizi krvne plazme pokazalo, da je vnos izdelkov obogatenih $\mathrm{z}$ alevronsko plastjo pšeničnih zrn znatno pripomogel k povečani koncentraciji mikrohranil in spojin, s potencialno oksidativnim delovanjem. Do podobnih zaključkov so prišli tudi Costabile in sod. (2008), ki so poudarili, da uživanje polnozrnate pšenice pripomore k povečani koncentraciji ferulne kisline $\mathrm{v}$ krvi (analizirali na tešče). Slednje je bil po njihovem mnenju dokaz konstantnega sproščanja antioksidantov v krvni obtok. Istočasno pa so v svoji študiji potrdili vlogo polnozrnatih žitnih zrn kot prebiotikov in ugotovili, da so pripravki za zajtrk iz polnozrnate pšenice bolj zaznamovali črevesno mikrobioto (povečala populacijo bifido- in mlečnokislinskih bakterij) kot pšenični otrobi.

\section{VEZANE FENOLNE SPOJINE KOT SES- TAVINA FUNKCIONALNIH ŽIVIL}

Dodatek vezanih fenolnih spojin v živilo je lahko idealno nadomestilo za aditive (antioksidativno delovanje) in konzervanse (protimikrobno delovanje). Načini vključevanja $\mathrm{v}$ živilo so različni. Priprava ekstraktov zahteva dodatno delo, uporabo topil, ustrezno opremo. Po drugi strani lahko prevelika količina $\mathrm{v}$ živilo dodanih vlaknin $\mathrm{z}$ vezanimi fenolnimi spojinami predstavlja tehnološko in senzorično omejitev, zato je ekstrakt pogosto priročnejša rešitev. $\mathrm{V}$ študiji, kjer so mesu dodali ekstrakte rženih in pšeničnih otrobov (Šulniūtè in sod., 2016) je to vodilo $v$ izboljšano oksidativno stabilnost mesnega izdelka in pripomoglo $\mathrm{k}$ večji vsebnosti bioaktivnih komponent $\mathrm{s}$ potencialno pozitivnim učinkom na zdravje. Tudi v primeru ajde se je izkazalo, da bi se ekstrakt fenolnih spojin pripravljen iz otrobov lahko uporabil kot sestavina $\mathrm{z}$ antioksidativnim delovanjem, $\mathrm{z}$ in vitro testom pa je bila potrjena tudi sposobnost zaviranja tvorbe in razvoja rakastih celic na jetrih ( $\mathrm{Li}$ in sod., 2016). Dodatek riževih otrobov (30 \%) je 5-krat povečal antioksidativno učinkovitost pšeničnega kru- 
ha, pri čemer bistveno ni vplival na splošno senzorično sprejemljivost (Irakli in sod., 2015). Vključitev ekstrakta riževih otrobov $\mathrm{v}$ piškote je pripomogla $\mathrm{k}$ manjši oksidaciji prisotnih maščob (Bhanger in sod. 2008). Nadalje, najnovejše raziskave kažejo na to, da kombinacija dveh ali več fitokemikalij različnega izvora pomembno vpliva na biološko učinkovitost ter razpoložljivost posamezne bioaktivne komponente (Gawlik-Dziki in sod. 2013; Phan in sod., 2018; Wang in Zhu, 2017). Podobne rezultate je dala tudi sočasna uporaba različnih žit. Raziskovalci (Serpen in sod., 2012) so poročali o sinergističnem in antagonističnem delovanju polnozrnatih pripravkov, ki so jih v različnih kombinacijah dodajali v kruh. Poleg izboljšane antioksidativne učinkovitosti, je uporaba ustrezne kombinacije semen vodila $v$ manjšo vsebnost akrilamida, učinkovito omejevanje tvorbe 5-hidroksimetilfurfurala in večjo koncentracijo furozina (Serpen in sod., 2012). Opozorimo še na izsledke nedavne raziskave, ki so jo izvedli Montemurro in sod. (2019). Ta je pokazala, da fermentacija kaljenih zrn pšenice, ječmena in kvinoje s kislim testom ne vpliva zgolj na fenolne spojine, ampak sočasno poveča vsebnost peptidov, prostih aminokislin, $\gamma$-aminomaslene kisline ter zmanjša koncentracijo fitinske kisline, kondenziranih taninov, rafinoze in inhibitorjev tripsina. Še več, s tako pripravljenimi zrni so obogatili kruhe iz pšenične moke in uspeli razviti senzorično sprejemljive izdelke $\mathrm{z}$ veliko prebavljivostjo proteinov in majhno dostopnostjo škroba.

\section{ZAKLJUČEK}

Potrebna so nova dognanja na področju sproščanja in ekstrakcije vezanih fenolnih spojin, da bodo ta lahko še učinkoviteje uporabljena kot funkcionalna sestavina živil. Stranski proizvodi žitno predelovalna industrije, zlasti otrobi, predstavljajo bogat in poceni vir bioaktivnih komponent in izkazujejo velik potencial za tovrstno uporabo v prihodnosti. Dodatek vezanih fenolnih spojin lahko izboljša kakovost živila in mu podaljša rok uporabe. Poleg izboljšane antioksidativne stabilnosti mesa in piškotov, je uporaba ustrezne kombinacije semen vodila $\mathrm{v}$ manjšo vsebnost akrilamida, učinkovito omejevanje tvorbe 5-hidroksimetilfurfurala in večjo koncentracijo furozina v kruhu. Fermentacija kaljenih polnozrnatih semen omogoča izboljšanje prehranske vrednosti izdelkov, poveča vsebnost peptidov, prostih aminokislin, $\gamma$-aminomaslene kisline ter zmanjša koncentracijo nekaterih antinutrientov. Omenjen pristop velja za varen, poceni in tradicionalen postopek in kot tak bo gotovo dobro sprejet tudi s strani potrošnika, saj ponuja izdelke sprejemljive senzorične in teh- nološke kakovosti. Razvijanje okusnejših polnozrnatih živil z dodano vrednostjo na eni strani ter sodelovanje industrije, strokovnjakov in vladnih predstavnikov na drugi, bo potrošniku gotovo pomagalo prepoznati, kupiti in zaužiti več tovrstnih izdelkov.

\section{VIRI}

Acosta-Estrada, B. A., Gutiérrez-Uribe, J. A., Serna-Saldívar, S. O. (2014). Bound phenolics in foods, a review. Food Chemistry, 152, 46-55. https://doi.org/10.1016/j.foodchem.2013.11.093

Alvarez-Jubete, L., Arendt, E. K., Gallagher, E. (2010). Nutritive value of pseudocereals and their increasing use as functional gluten-free ingredients. Trends in Food Science \& Technology, 21(2), 106-113. https://doi.org/10.1016/j. tifs.2009.10.014

Alves, G. H., Ferreira, C. D., Vivian, P. G., Monks, J. L. F., Elias, M. C., Vanier, N. L., de Oliveira, M. (2016). The revisited levels of free and bound phenolics in rice: Effects of the extraction procedure. Food Chemistry, 208, 116-123. https://doi.org/10.1016/j.foodchem.2016.03.107

Anokwuru, C., Sigidi, M., Boukandou, M., Tshisikhawe, P., Traore, A., Potgieter, N. (2018). Antioxidant activity and spectroscopic characteristics of extractable and nonextractable phenolics from Terminalia sericea Burch. ex DC. Molecules, 23(6), 1303. https://doi.org/10.3390/molecules23061303

Antognoni, F., Mandrioli, R., Potente, G., Taneyo Saa, D. L., Gianotti, A. (2019). Changes in carotenoids, phenolic acids and antioxidant capacity in bread wheat doughs fermented with different lactic acid bacteria strains. Food Chemistry, 292, 211-216. https://doi.org/10.1016/j.foodchem.2019.04.061

Arranz, S. \& Saura Calixto, F. (2010). Analysis of polyphenols in cereals may be improved performing acidic hydrolysis: A study in wheat flour and wheat bran and cereals of the diet. Journal of Cereal Science, 51(3), 313-318. https://doi. org/10.1016/j.jcs.2010.01.006

Bhanger, M. I., Iqbal, S., Anwar, F., Imran, M., Akhtar, M., Zia-ul-Haq, M. (2008). Antioxidant potential of rice bran extracts and its effects on stabilisation of cookies under ambient storage. International Journal of Food Science \& Technology, 43(5), 779-786. https://doi.org/10.1111/j.13652621.2007.01515. $\mathrm{x}$

Boubakri, H., Jdey, A., Taamalli, A., Taamalli, W., Jebara, M., Brini, F., Riciputi, Y., Pasini, F., Christian, M., Verardo, V. (2017). Phenolic composition as measured by liquid chromatography/mass spectrometry and biological properties of Tunisian barley. International Journal of Food Properties, 20(2), 1783-1797. https://doi.org/10.1080/10942912.2017. 1359186

Boue, S. M., Daigle, K. W., Chen, M.-H., Cao, H., Heiman, M. L. (2016). Antidiabetic potential of purple and red rice (Oryza sativa L.) bran extracts. Journal of Agricultural and Food Chemistry, 64(26), 5345-5353. https://doi.org/10.1021/acs. jafc.6b01909 
Cai, S., Wang, O., Wang, M., He, J., Wang, Y., Zhang, D., Zhou, F., Ji, B. (2012). In vitro inhibitory effect on pancreatic lipase activity of subfractions from ethanol extracts of fermented oats (Avena sativa L.) and synergistic effect of three phenolic acids. Journal of Agricultural and Food Chemistry, 60(29), 7245-7251. https://doi.org/10.1021/jf3009958

Călinoiu, L. F. \& Vodnar, D. C. (2018). Whole grains and phenolic acids: A review on bioactivity, functionality, health benefits and bioavailability. Nutrients, 10(11), 1615. https://doi.org/ 10.3390/nu10111615

Chandrasekara, A. \& Shahidi F. (2011). Determination of antioxidant activity in free and hydrolyzed fractions of millet grains and characterization of their phenolic profiles by HPLC-DAD-ESI-MSn. Journal of Functional Foods, 3(3), 144-158. https://doi.org/10.1016/j.jff.2011.03.007

Chen, P. X., Tang, Y., Zhang, B., Liu, R., Marcone, M. F., Li, X., Tsao, R. (2014). 5-Hydroxymethyl-2-furfural and derivatives formed during acid hydrolysis of conjugated and bound phenolics in plant foods and the effects on phenolic content and antioxidant capacity. Journal of Agricultural and Food Chemistry, 62(20), 4754-4761. https://doi. org/10.1021/jf500518r

Chen, Z., Ma, Y., Yang, R., Gu, Z., Wang, P. (2019). Effects of exogenous $\mathrm{Ca}^{2+}$ on phenolic accumulation and physiological changes in germinated wheat (Triticum aestivum L.) under UV-B radiation. Food Chemistry, 288, 368-376. https://doi.org/10.1016/j.foodchem.2019.02.131

Chen, Z., Wang, P., Weng, Y., Ma, Y., Gu, Z., Yang, R. (2017). Comparison of phenolic profiles, antioxidant capacity and relevant enzyme activity of different Chinese wheat varieties during germination. Food Bioscience, 20, 159-167. https://doi.org/10.1016/j.fbio.2017.10.004

Costabile, A., Klinder, A., Fava, F., Napolitano, A., Fogliano, V., Leonard, C., Gibson, G. R., Tuohy, K. M. (2008). Wholegrain wheat breakfast cereal has a prebiotic effect on the human gut microbiota: a double-blind, placebo-controlled, crossover study. British Journal of Nutrition, 99(1), 110-120. https://doi.org/ 10.1017/s0007114507793923

Dahmoune, F., Spigno, G., Moussi, K., Remini, H., Cherbal, A., Madani, K. (2014). Pistacia lentiscus leaves as a source of phenolic compounds: Microwave-assisted extraction optimized and compared with ultrasound-assisted and conventional solvent extraction. Industrial Crops and Products, 61, 31-40. https://doi.org/10.1016/j.indcrop.2014.06.035

Das, A.K., Adsare, S.R., Das, M., Kulthe, P.S., Ganesan, P. (2017). Advanced techniques in extraction of phenolics from cereals, pulses, fruits, and vegetables. V M.W. Siddiqui, V. Bansal, K. Prasad (Ur), Plant Secondary Metabolites, vol 2: Stimulation, Extraction and Utilization (str. 27-76).: New York, NY: Apple Academic Press, Inc.

de Oliveira, D. M., Finger-Teixeira, A., Rodrigues Mota, T., Salvador, V. H., Moreira-Vilar, F. C., Correa Molinari, H. B., Craig Mitchell, R. A., Marchiosi, R., Ferrarese-Filho, O., Dantas dos Santos, W. (2015). Ferulic acid: a key component in grass lignocellulose recalcitrance to hydrolysis. Plant Biotechnology Journal, 13(9), 1224-1232. https://doi. org/ 10.1111/pbi.12292

Dykes, L. \& Rooney, W. (2007). Phenolic compounds in cereal grains and their health benefits. Cereal Foods World, 52, 105-111.

Domínguez-Rodríguez, G., Marina, M. L., Plaza, M. (2017). Strategies for the extraction and analysis of non-extractable polyphenols from plants. Journal of Chromatography A, 1514, 1-15. https://doi.org/10.1016/j.chroma.2017.07.066

Falcinelli, B., Benincasa, P., Calzuola, I., Gigliarelli, L., Lutts, S., Marsili, V. (2017). Phenolic content and antioxidant activity in raw and denatured aqueous extracts from sprouts and wheatgrass of einkorn and emmer obtained under salinity. Molecules, 22(12), 2132. https://doi: 10.3390/molecules 22122132

Faulds, C. B. (2010). What can feruloyl esterases do for us? Phytochemistry Reviews, 9(1), 121-132. https://doi. org/10.1007/s11101-009-9156-2

Gan, R.-Y., Lui, W.-Y., Wu, K., Chan, C.-L., Dai, S.-H., Sui, Z.Q., Corke, H. (2017). Bioactive compounds and bioactivities of germinated edible seeds and sprouts: An updated review. Trends in Food Science \& Technology, 59, 1-14. https://doi.org/10.1016/j.tifs.2016.11.010

Gangopadhyay, N., Hossain, M. B., Rai, D. K., Brunton, N. P. (2015). A review of extraction and analysis of bioactives in oat and barley and scope for use of novel food processing technologies. Molecules, 20(6), 10884-10909. https:// doi: 10.3390/molecules200610884

Gänzle, M. G. (2014). Enzymatic and bacterial conversions during sourdough fermentation. Food Microbiology, 37, 2-10. https://doi.org/10.1016/j.fm.2013.04.007

Gawlik-Dziki, U., Swieca, M., Dziki, D. (2012). Comparison of phenolic acids profile and antioxidant potential of six varieties of spelt (Triticum spelta L.). Journal of Agricultural and Food Chemistry, 60(18), 4603-4612. https://doi: $10.1021 /$ jf3011239

Gawlik-Dziki, U., Świeca, M., Dziki, D., Baraniak, B., Tomiło, J., Czyż, J. (2013). Quality and antioxidant properties of breads enriched with dry onion (Allium cepa L.) skin. Food Chemistry, 138(2), 1621-1628. https://doi.org/10.1016/j. foodchem.2012.09.151

Gobbetti, M., De Angelis, M., Di Cagno, R., Calasso, M., Archetti, G., Rizzello, C. G. (2019). Novel insights on the functional/nutritional features of the sourdough fermentation. International Journal of Food Microbiology, 302, 103-113. https://doi.org/10.1016/j.ijfoodmicro.2018.05.018

Golob, K. (2018). Vpliv osvetljevanja s svetlobo različnih valovnih dolžin na antioksidativni potencial kaljene pšenice : magistrsko delo.Ljubljana: Biotehniška fakulteta, Oddelek za živilstvo.

Gunenc, A., HadiNezhad, M., Farah, I., Hashem, A., Hosseinian, F. (2015). Impact of supercritical $\mathrm{CO}_{2}$ and traditional solvent extraction systems on the extractability of alkylresorcinols, phenolic profile and their antioxidant activity in wheat bran. Journal of Functional Foods, 12, 109-119. https://doi.org/10.1016/j.jff.2014.10.024

Hemalatha, P., Bomzan, D. P., Sathyendra, Rao B. V., Sreerama, Y. N. (2016). Distribution of phenolic antioxidants in whole and milled fractions of quinoa and their inhibitory effects on $\alpha$-amylase and $\alpha$-glucosidase activities. Food Chemistry, 199, 330-338. https://doi.org/10.1016/j.foodchem.2015.12.025 
Hole, A. S., Rud, I., Grimmer, S., Sigl, S., Narvhus, J., Sahlstrøm, S. (2012). Improved bioavailability of dietary phenolic acids in whole grain barley and oat groat following fermentation with probiotic Lactobacillus acidophilus, Lactobacillus johnsonii, and Lactobacillus reuteri. Journal of Agricultural and Food Chemistry, 60(25), 6369-6375. https:// doi.org/10.1021/jf300410h

Hübner, F. \& Arendt, E. K. (2013). Germination of cereal grains as a way to improve the nutritional value: A Review. Critical Reviews in Food Science and Nutrition, 53(8), 853-861. https://doi.org/10.1080/10408398.2011.562060

Hung, P. V., Hatcher, D. W., Barker, W. (2011). Phenolic acid composition of sprouted wheats by ultra-performance liquid chromatography (UPLC) and their antioxidant activities. Food Chemistry, 126(4), 1896-1901. https://doi. org/10.1016/j.foodchem.2010.12.015

Irakli, M., Katsantonis, D., Kleisiaris, F. (2015). Evaluation of quality attributes, nutraceutical components and antioxidant potential of wheat bread substituted with rice bran. Journal of Cereal Science, 65, 74-80. https://doi. org/10.1016/j.jcs.2015.06.010

Irakli, M., Kleisiaris, F., Kadoglidou, K., Katsantonis, D. (2018). Optimizing extraction conditions of free and bound phenolic compounds from rice by-products and their antioxidant effects. Foods, 7(6), 93. https://doi.org/10.3390/ foods7060093

Irakli, M. N., Samanidou, V. F., Biliaderis, C. G., Papadoyannis, I. N. (2012a). Development and validation of an HPLCmethod for determination of free and bound phenolic acids in cereals after solid-phase extraction. Food Chemistry, 134(3), 1624-1632. https://doi.org/10.1016/j.foodchem.2012.03.046

Irakli, M. N., Samanidou, V. F., Biliaderis, C. G., Papadoyannis, I. N. (2012b). Simultaneous determination of phenolic acids and flavonoids in rice using solid-phase extraction and RP-HPLC with photodiode array detection. Journal of Separation Science, 35(13), 1603-1611. https://doi. org/10.1002/jssc.201200140

Katina, K., Liukkonen, K. H., Kaukovirta-Norja, A., Adlercreutz, H., Heinonen, S. M., Lampi, A. M., Pihlava, J. M., Poutanen, K. (2007). Fermentation-induced changes in the nutritional value of native or germinated rye. Journal of Cereal Science, 46(3), 348-355. https://doi.org/10.1016/j. jcs.2007.07.006

Kim, K.-H., Tsao, R., Yang, R., Cui, S. W. (2006). Phenolic acid profiles and antioxidant activities of wheat bran extracts and the effect of hydrolysis conditions. Food Chemistry, 95(3), 466-473. https://doi.org/10.1016/j.foodchem.2005.01.032

Kim, M. J., Kwak, H. S., Kim, S. S. (2018). Effects of germination on protein, $\gamma$-aminobutyric acid, phenolic acids, and antioxidant capacity in wheat. Molecules,,23(9), 2244. https://doi.org/10.3390/molecules23092244

Koistinen, V. M. \& Hanhineva, K. (2017). Mass spectrometrybased analysis of whole-grain phytochemicals. Critical Reviews in Food Science and Nutrition, 57(8), 1688-1709. https://doi.org/10.1080/10408398.2015.1016477

Konopka, I., Tańska, M., Faron, A., Czaplicki, S. (2014). Release of free ferulic acid and changes in antioxidant properties during the wheat and rye bread making process. Food Science and Biotechnology, 23(3), 831-840. https://doi. org/10.1007/s10068-014-0112-6

Krek, M. (2018). Vpliv osvetljevanja s svetlobo različnih valovnih dolžin na antioksidativni potencial kaljene pire : magistrsko delo. Ljubljana: Biotehniška fakulteta, Oddelek za živilstvo.

Kumar, P., Yadav, D., Kumar, P., Panesar, P. S., Bunkar, D. S., Mishra, D., Chopra, H. K. (2016). Comparative study on conventional, ultrasonication and microwave assisted extraction of $\gamma$-oryzanol from rice bran. Journal of food science and technology, 53(4), 2047-2053. https://doi. org/10.1007/s13197-016-2175-2

Li, F., Zhang, X., Zheng, S., Lu, K., Zhao, G., Ming, J. (2016). The composition, antioxidant and antiproliferative capacities of phenolic compounds extracted from tartary buckwheat bran (Fagopyrum tartaricum (L.) Gaerth). Journal of Functional Foods, 22, 145-155. https://doi.org/10.1016/j. jff.2016.01.027

Liyana-Pathirana, C. M. \& Shahidi, F. (2006). Importance of insoluble-bound phenolics to antioxidant properties of wheat. Journal of Agricultural and Food Chemistry, 54(4), 1256-1264. https://doi.org/10.1021/jf052556h

Liyana-Pathirana, C. M. \& Shahidi, F. (2007). The antioxidant potential of milling fractions from breadwheat and durum. Journal of Cereal Science, 45(3), 238-247. https://doi. org/10.1016/j.jcs.2006.08.007

Ma, Y., Wang, P., Wang, M., Sun, M., Gu, Z., Yang, R. (2019). GABA mediates phenolic compounds accumulation and the antioxidant system enhancement in germinated hulless barley under $\mathrm{NaCl}$ stress. Food Chemistry, 270, 593601. https://doi.org/10.1016/j.foodchem.2018.07.092

Madhujith, T. \& Shahidi, F. (2007). Antioxidative and antiproliferative properties of selected barley (Hordeum vulgarae L.) cultivars and their potential for inhibition of lowdensity lipoprotein (LDL) cholesterol oxidation. Journal of Agricultural and Food Chemistry, 55(13), 5018-5024. https://doi.org/10.1021/jf070072a

Mir, N. A., Riar, C. S., Singh, S. (2018). Nutritional constituents of pseudo cereals and their potential use in food systems: A review. Trends in Food Science \& Technology, 75, 170180. https://doi.org/10.1016/j.tifs.2018.03.016

Montemurro, M., Pontonio, E., Gobbetti, M., Rizzello, C. G. (2019). Investigation of the nutritional, functional and technological effects of the sourdough fermentation of sprouted flours. International Journal of Food Microbiology, 302, 47-58. https://doi.org/10.1016/j.ijfoodmicro.2018.08.005

Moore, J., Cheng, Z., Hao, J., Guo, G., Liu, J.-G., Lin, C., Yu, L. (2007). Effects of solid-state yeast treatment on the antioxidant properties and protein and fiber compositions of common hard wheat bran. Journal of Agricultural and Food Chemistry, 55(25), 10173-10182. https://doi. org/10.1021/jf071590o

Musa-Veloso, K., Poon, T., Harkness, L. S., O‘Shea, M., Chu, Y. (2018). The effects of whole-grain compared with refined wheat, rice, and rye on the postprandial blood glucose response: a systematic review and meta-analysis of randomized controlled trials. The American Journal of Clinical 
Nutrition, 108(4), 759-774. https://doi.org/10.1093/ajcn/ nqy112

Niroula, A., Khatri, S., Khadka, D., Timilsina, R. (2019). Total phenolic contents and antioxidant activity profile of selected cereal sprouts and grasses. International Journal of Food Properties, 22(1), 427-437. https://doi.org/10.1080/10 942912.2019.1588297

Oghbaei, M.\& Prakash, J. (2016). Effect of primary processing of cereals and legumes on its nutritional quality: A comprehensive review. Cogent Food \& Agriculture, 2(1), 1136015. https://doi.org/10.1080/23311932.2015.1136015

Oliveira, D. M., Mota, T. R., Oliva, B., Segato, F., Marchiosi, R., Ferrarese-Filho, O., Faulds, C. B., dos Santos, W. D. (2019). Feruloyl esterases: Biocatalysts to overcome biomass recalcitrance and for the production of bioactive compounds. Bioresource Technology, 278, 408-423. https://doi. org/10.1016/j.biortech.2019.01.064

Pang, Y., Ahmed, S., Xu, Y., Beta, T., Zhu, Z., Shao, Y., Bao, J. (2018). Bound phenolic compounds and antioxidant properties of whole grain and bran of white, red and black rice. Food Chemistry, 240, 212-221. https://doi. org/10.1016/j.foodchem.2017.07.095

Paucar-Menacho, L. M., Martínez-Villaluenga, C., Dueñas, M., Frias, J., Peñas, E. (2017). Optimization of germination time and temperature to maximize the content of bioactive compounds and the antioxidant activity of purple corn (Zea mays L.) by response surface methodology. LWT - Food Science and Technology, 76, 236-244. https:// doi.org/10.1016/j.lwt.2016.07.064

Phan, M. A. T., Paterson, J., Bucknall, M., Arcot, J. (2018). Interactions between phytochemicals from fruits and vegetables: Effects on bioactivities and bioavailability. Critical Reviews in Food Science and Nutrition, 58(8), 1310-1329. https://doi.org/10.1080/10408398.2016.1254595

Pradeep, P. M., Sreerama, Y. N. (2017). Soluble and bound phenolics of two different millet genera and their milled fractions: Comparative evaluation of antioxidant properties and inhibitory effects on starch hydrolysing enzyme activities. Journal of Functional Foods, 35, 682-693. https:// doi.org/10.1016/j.jff.2017.06.033

Price, R. K., Wallace, J. M. W., Hamill, L. L., Keaveney, E. M., Strain, J. J., Parker, M. J., Welch, R. W. (2012). Evaluation of the effect of wheat aleurone-rich foods on markers of antioxidant status, inflammation and endothelial function in apparently healthy men and women. British Journal of Nutrition, 108(9), 1644-1651. https://doi.org/10.1017/ s0007114511007070

Ribas-Agustí, A., Martín-Belloso, O., Soliva-Fortuny, R., ElezMartínez, P. (2018). Food processing strategies to enhance phenolic compounds bioaccessibility and bioavailability in plant-based foods. Critical Reviews in Food Science and Nutrition, 58(15), 2531-2548. https://doi.org/10.1080/104 08398.2017.1331200

Serpen, A., Capuano, E., Fogliano, V., Gökmen, V. (2007). A new procedure to measure the antioxidant activity of insoluble food components. Journal of Agricultural and Food Chemistry, 55(19), 7676-7681. https://doi.org/10.1021/ jf071291z

Serpen, A., Gökmen, V., Mogol, B. A. (2012). Effects of dif- ferent grain mixtures on Maillard reaction products and total antioxidant capacities of breads. Journal of Food Composition and Analysis, 26(1), 160-168. https://doi. org/10.1016/j.jfca.2012.02.001

Shi, J., Shan, S., Li, Z., Li, H., Li, X., Li, Z. (2015). Bound polyphenol from foxtail millet bran induces apoptosis in HCT-116 cell through ROS generation. Journal of Functional Foods, 17, 958-968. https://doi.org/10.1016/j. jff.2015.06.049

Singh, A. \& Sharma, S. (2017). Bioactive components and functional properties of biologically activated cereal grains: A bibliographic review. Critical Reviews in Food Science and Nutrition, 57(14), 3051-3071. https://doi.org/ 10.1080/10408398.2015.1085828

Singh, A. K., Rehal, J., Kaur, A., Jyot, G. (2015). Enhancement of attributes of cereals by germination and fermentation: A review. Critical Reviews in Food Science and Nutrition, 55(11), 1575-1589. https://doi.org/10.1080/10408398.201 2.706661

Slavin, J. (2003). Why whole grains are protective: biological mechanisms. Proceedings of the Nutrition Society, 62(1), 129-134. https://doi.org/10.1079/pns2002221

Šulniūte, V., Jaime, I., Rovira, J., Venskutonis, P. R. (2016). Rye and wheat bran extracts isolated with pressurized solvents increase oxidative stability and antioxidant potential of beef meat hamburgers. Journal of Food Science, 81(2), H519-H527. https://doi.org/10.1111/1750-3841.13197

Tang, Y., Zhang, B., Li, X., Chen, P. X., Zhang, H., Liu, R., Tsao, R. (2016). Bound phenolics of quinoa seeds released by acid, alkaline, and enzymatic treatments and their antioxidant and $\alpha$-glucosidase and pancreatic lipase inhibitory effects. Journal of Agricultural and Food Chemistry, 64(8), 1712-1719. https://doi.org/10.1021/acs.jafc.5b05761

Terpinc, P., Abramovič, H. (2010). A kinetic approach for evaluation of the antioxidant activity of selected phenolic acids. Food Chemistry, 121(2), 366-371. https://doi. org/10.1016/j.foodchem.2009.12.037

Terpinc, P., Cigić, B., Polak, T., Hribar, J., Požrl, T. (2016). LC-MS analysis of phenolic compounds and antioxidant activity of buckwheat at different stages of malting. Food Chemistry, 210, 9-17. https://doi.org/10.1016/j.foodchem.2016.04.030

Terpinc, P., Polak, T., Poklar Ulrih, N., Abramovič, H. (2011). Effect of heat treatment of camelina (Camelina sativa) seeds on the antioxidant potential of their extracts. Journal of Agricultural and Food Chemistry, 59(16), 8639-8645. https://doi.org/10.1021/jf2016072

Terpinc, P., Polak, T., Šegatin, N., Hanzlowsky, A., Ulrih, N. P., Abramovič, H. (2011). Antioxidant properties of 4-vinyl derivatives of hydroxycinnamic acids. Food Chemistry, 128(1), 62-69. https://doi.org/10.1016/j.foodchem.2011.02.077

Ti, H., Zhang, R., Zhang, M., Li, Q., Wei, Z., Zhang, Y., Tang, X., Deng, Y., Liu, L., Ma, Y. (2014). Dynamic changes in the free and bound phenolic compounds and antioxidant activity of brown rice at different germination stages. Food Chemistry, 161, 337-344. https://doi.org/10.1016/j.foodchem.2014.04.024

Van Hung, P. (2016). Phenolic Compounds of cere- 
als and their antioxidant capacity. Critical Reviews in Food Science and Nutrition, 56(1), 25-35. https:// doi: 10.1080/10408398.2012.708909

Verma, B., Hucl, P., Chibbar, R. N. (2009). Phenolic acid composition and antioxidant capacity of acid and alkali hydrolysed wheat bran fractions. Food Chemistry, 116(4), 947-954. https://doi.org/10.1016/j.foodchem.2009.03.060

Wang, J., Sun, B., Cao, Y., Tian, Y., Li, X. (2008). Optimisation of ultrasound-assisted extraction of phenolic compounds from wheat bran. Food Chemistry, 106(2), 804-810. https:// doi.org/10.1016/j.foodchem.2007.06.062

Wang, S., Zhu, F. (2017). Dietary antioxidant synergy in chemical and biological systems. Critical Reviews in Food Science and Nutrition, 57(11), 2343-2357. https://doi.org/10.1 080/10408398.2015.1046546

Wang, T., He, F., Chen, G. (2014). Improving bioaccessibility and bioavailability of phenolic compounds in cereal grains through processing technologies: A concise review. Journal of Functional Foods, 7, 101-111. https://doi. org/10.1016/j.jff.2014.01.033

Wang, W., Guo, J., Zhang, J., Peng, J., Liu, T., Xin, Z. (2015). Isolation, identification and antioxidant activity of bound phenolic compounds present in rice bran. Food Chemistry, 171, 40-49. https://doi.org/10.1016/j.foodchem.2014.08.095

Xiang, N., Guo, X., Liu, F., Li, Q., Hu, J., Brennan, C. S. (2017). Effect of light- and dark-germination on the phenolic biosynthesis, phytochemical profiles, and antioxidant activities in sweet corn (Zea mays L.) Sprouts. International journal of molecular sciences, 18(6), 1246. https://doi. org/10.3390/ijms18061246
Xu, J. G., Tian, C. R., Hu, Q. P., Luo, J. Y., Wang, X. D., Tian, X. D. (2009). Dynamic changes in phenolic compounds and antioxidant activity in oats (Avena nuda L.) during steeping and germination. Journal of Agricultural and Food Chemistry, 57(21), 10392-10398. https://doi.org/10.1021/ jf902778j

Xu, M., Rao, J., Chen, B. (2019). Phenolic compounds in germinated cereal and pulse seeds: Classification, transformation, and metabolic process. Critical Reviews in Food Science and Nutrition, 1-20. https://doi.org/10.1080/1040 8398.2018.1550051

Yang, F., Basu, T. K, Ooraikul, B. (2001). Studies on germination conditions and antioxidant contents of wheat grain. International Journal of Food Sciences and Nutrition, 52(4), 319-330. https://doi.org/10.1080/09637480120057567

Yu, L., Zhou, K., \& Parry, W. J. (2005). Inhibitory effects of wheat bran extracts on human LDL oxidation and free radicals. LWT - Food Science and Technology, 38(5), 463470. https://doi.org/10.1016/j.lwt.2004.07.005

Zhang, J., Ding, Y., Dong, H., Hou, H., Zhang, X. (2018). Distribution of phenolic acids and antioxidant activities of different bran fractions from three pigmented wheat varieties. Journal of Chemistry, 2018, 1-9. https://doi. org/10.1155/2018/6459243

Zhu, Y., Li, T., Fu, X., Abbasi, A. M., Zheng, B., Liu, R. H. (2015). Phenolics content, antioxidant and antiproliferative activities of dehulled highland barley (Hordeum vulgare L.). Journal of Functional Foods, 19, 439-450. https://doi. org/10.1016/j.jff.2015.09.053 